\title{
Non-esterified fatty acid and glycerol kinetics and fatty acid re-esterification in goats during early lactation
}

\author{
BY F. R. DUNSHEA* AND A. W. BELL† \\ School of Agriculture, La Trobe University, Bundoora, Victoria 3083, Australia \\ AND T. E. TRIGG甘 \\ Animal and Irrigated Pastures Research Institute, Kyabram, Victoria 3620, Australia
}

(Received 16 May 1989 - Accepted 5 February 1990)

\begin{abstract}
Non-esterified fatty acid (NEFA) and glycerol kinetics were studied in lactating goats to gain insight into the mechanisms by which animals in early lactation can initially mobilize and later replenish body fat reserves. Kinetic measurements were made at days 10,38 and 76 post-partum in ten multiparous lactating does. Plasma NEFA concentrations and NEFA entry rate decreased as lactation advanced, being significantly higher at day 10 than at either days 38 or 76 of lactation. Both plasma NEFA concentrations and NEFA entry rate were negatively correlated with calculated energy balance. In contrast, glycerol entry rate was significantly higher at day 76 than at day 10 of lactation and was positively related to both calculated energy intake and energy balance. Apparent intracellular fatty acid re-esterification was lower at day 10 than at later stages of lactation and was positively related to calculated energy balance. It is suggested that during early lactation, substantial shifts in adipose tissue fat reserves can occur via altering rates of fatty acid re-esterification and de novo lipogenesis, without major changes in the rate of lipolysis.
\end{abstract}

Non-esterified fatty acids: Glycerol: Lactation: Goat

Adipose tissue lipid is mobilized to provide energy for milk secretion during early lactation. The major storage form of lipid is triacylglycerol which upon complete hydrolysis (lipolysis) yields $3 \mathrm{~mol}$ non-esterified fatty acids (NEFA) and $1 \mathrm{~mol}$ glycerol $/ \mathrm{mol}$ triacylglycerol. The NEFA liberated during lipolysis can be either released into the circulation or re-esterified into newly formed triacylglycerols. Therefore, NEFA entry rate (NER) may often underestimate the true rate of lipolysis. Conversely, as adipose tissue contains very little glycerol kinase (EC 2.7.1.30) (Shirley et al. 1973), glycerol released during lipolysis must enter the free body pool and so the glycerol entry rate (GER) should provide a better estimate of lipolysis.

NEFA kinetics have been related to the productive performance of ruminants in several physiological states, including lactation (Bauman et al. 1988; Dunshea et al. 1989). However, very little is known about the dynamics of glycerol metabolism in ruminants, especially during lactation.

The aim of the present study was to use tracer techniques and an in vivo approach to examine the relationships between NEFA and glycerol kinetics, energy status and fat mobilization in goats during early lactation. Some of these findings have been reported in abridged form (Dunshea \& Bell, 1987, 1989).

Present addresses: * Animal Research Institute, Werribee, Victoria 3030, Australia. $\dagger$ Department of Animal Science, Cornell University, Ithaca, NY 14853, USA. †Peptide Technology, PO Box 444, Dee Why, NSW 2099 , Australia.

$\S$ For reprints. 


\section{MATERIALS AND METHODS}

Animals and feeding

Twelve multiparous Saanen does, aged 3-6 years and weighing 44-62 kg, were used in this series of experiments. Additional information on animal treatment and pre-partum management are given elsewhere (Dunshea et al. 1990). Kids were removed immediately after parturition and the does were then machine-milked. Thereafter, goats were milked twice daily at approximately 08.00 and 16.00 hours. On the day before and the day of an experiment, portions of milk were obtained at each milking and analysed for milk lactose, fat and protein concentrations using an infra-red milk analyser (Milkoscan; Foss, Switzerland).

All goats received ad lib. a diet of lucerne (Medicago sativa) chaff-whole oat (Avena sativa) grain-rolled lupins (Lupinus albus) $(65: 25: 10$, by wt). Feed was offered twice daily except for $4 \mathrm{~d}$ before and until $1 \mathrm{~d}$ after the continuous infusions. During this time the goats were fed every $2 \mathrm{~h}$ via a belt-driven automatic feeding system. The diet contained $182 \mathrm{~g}$ crude protein and $10.0 \mathrm{MJ}$ metabolizable energy $(\mathrm{ME}) / \mathrm{kg}$ dry matter. ME content was based on the apparent digestibility of organic matter (Ministry of Agriculture, Fisheries and Food, 1975) determined in eight of the does during the 8th week of lactation. Dry matter, organic matter and nitrogen digestibilities were $0.664,0.665$ and 0.759 respectively.

\section{Experimental procedure}

Kinetic measurements were made three times during lactation, at 10 (SE 0.5), 38 (SE 1.1) and 76 (SE 2.1) d post-partum. Polyethylene catheters $(0.80 \mathrm{~mm}$ i.d., $1.20 \mathrm{~mm}$ o.d.; Dural Plastics, Dural, NSW, Australia) were inserted at least $24 \mathrm{~h}$ before an experiment. In nine goats which had been surgically prepared with carotid loops (Hecker, 1974) at least 2 months before parturition, the infusion and sampling catheters were inserted $15 \mathrm{~cm}$ into a jugular vein and common carotid artery respectively. In the remaining three goats the sampling catheter was positioned in the right ventricle via the jugular vein contralateral to the infusion catheter (Linzell, 1966). Two of the goats became ill between days 10 and 38 of lactation and did not complete the study, therefore values from these two animals at day 10 of lactation were included in the regression analysis but not in comparisons between stages of lactation.

Infusions. All NEFA infusates contained an equimolar mixture of $\left[1-{ }^{14} \mathrm{C}\right]$ palmitic, $\left[1-{ }^{14} \mathrm{C}\right]$ stearic and $\left[1-{ }^{14} \mathrm{C}\right]$ oleic acids $(56-57 \mathrm{mCi} / \mathrm{mmol}$; Amersham International plc, Amersham, Bucks) and were prepared by a modification of the method of Lindsay \& Leat (1977) as outlined by Dunshea et al. $(1988 a)$. Briefly, to $60 \mu \mathrm{Ci}$ mixed NEFA in ethanol $(30 \mu \mathrm{Ci} / \mathrm{ml})$ was added $3 \mathrm{mg}$ each of carrier palmitic, stearic and oleic acids and $10 \mu \mathrm{l}$ of 1 M-potassium hydroxide. After drying the solution under a gentle stream of nitrogen gas, $10 \mathrm{ml}$ warm saline $\left(9 \mathrm{~g}\right.$ sodium chloride $\left./ 1 ; 60^{\circ}\right)$ was added and the potassium soaps of the NEFA were dissolved by maintaining this solution at $60^{\circ}$ for $30 \mathrm{~min}$. The solution was filtered through a $0.22 \mu \mathrm{m}$ disposable filter (Millex-GS; Millipore, Ma., USA) into $15 \mathrm{ml}$ plasma freshly obtained from the experimental goat, and which was gently stirring on a magnetic hot plate at $40^{\circ}$. The infusate was diluted to $50 \mathrm{ml}$ with saline and drawn into a $50 \mathrm{ml}$ disposable syringe. $\left[2-{ }^{3} \mathrm{H}\right]$ glycerol $(1 \mathrm{Ci} / \mathrm{mmol}$; Amersham International plc) in ethanol was dried under a gentle stream of $\mathrm{N}_{2}$ and reconstituted in sterile saline to a final activity of $30 \mu \mathrm{Ci} / \mathrm{ml}$ and stored at $4^{\circ}$. Of this stock, $10 \mathrm{ml}$ were diluted with $40 \mathrm{ml}$ sterile saline and used for infusion. Simultaneous infusions of $\left[1-{ }^{14} \mathrm{C}\right] \mathrm{NEFA}$ and $\left[2-{ }^{3} \mathrm{H}\right] \mathrm{glycerol}$ were performed using a dual-syringe pump (Vial Medical, France) at $12.5 \mathrm{ml} / \mathrm{h}(15$ and $75 \mu \mathrm{Ci} / \mathrm{h}$ respectively) for $3.5 \mathrm{~h}$. Blood sampling $(10 \mathrm{ml})$ for plasma NEFA, glycerol and 
glucose concentrations and specific radioactivity (SRA) commenced after $90 \mathrm{~min}$ and eight blood samples were taken at equally spaced intervals over the next $120 \mathrm{~min}$. Blood samples were collected into syringes containing $\mathrm{Na}_{2}$ EDTA $(1 \mathrm{~g} / \mathrm{l})$ as an anticoagulant, sealed and immediately stored on ice. Within $1 \mathrm{~h}$ of sampling, blood was centrifuged for $15 \mathrm{~min}$ at $2000 \mathrm{~g}$ and $4^{\circ}$ to obtain plasma. For determination of plasma NEFA concentration and SRA the plasma lipids were extracted within $1 \mathrm{~h}$. Plasma for other analyses was stored at $-20^{\circ}$

\section{Chemical analyses}

NEFA. Plasma NEFA were isolated by a modification of the back-extraction method of Pethick et al. (1983). The modification was that $\left[9,10(n)-{ }^{3} \mathrm{H}\right]$ palmitic acid (1 nCi, $500 \mathrm{mCi} / \mathrm{mmol}$; Amersham International plc) was added to the plasma to determine recovery of extracted and derivatized NEFA (Dunshea et al. 1988a). Isolated NEFA were converted to their methyl esters by refluxing in $2.0 \mathrm{ml}$ sulphuric acid in methanol $(70 \mathrm{~g} / \mathrm{l})$ for $2 \mathrm{~h}$. Heptane $(4 \mathrm{ml})$ and $1.0 \mathrm{ml} \mathrm{NaCl}(40 \mathrm{~g} / \mathrm{l})$ were added with mixing and the heptane layer containing the fatty acid methyl esters was transferred to a scintillation vial. Heptane was removed by evaporation under a gentle stream of $\mathrm{N}_{2}$ gas and the fatty acid methyl esters were reconstituted in $25 \mu \mathrm{l}$ heptane. Duplicate $0.5 \mu \mathrm{l}$ samples were injected onto a $2 \mathrm{~m} \times 3 \mathrm{~mm}$ glass column packed with $10 \%$ SP-216-PS on 100-110 mesh Supelcoport (Supelco; Bellefonte, Pa., USA) in a Perkin Elmer F 11 gas-liquid chromatograph at $165^{\circ}$. The molar concentrations of the individual NEFA were determined by comparison with the internal standard (150 nmol pentadecanoic acid; Sigma, St Louis, Mo., USA) and use of appropriate correction factors. The remainder of the sample was dissolved in $5.0 \mathrm{ml}$ scintillation fluid (Anderson \& MacClure, 1973) and counted in a Packard Tri-Carb 460C liquid-scintillation system set in the dual-label mode. Recovery of $\left[9,10(n){ }^{3} \mathrm{H}\right]$ palmitic acid was $75-80 \%$ complete. Infusate radioactivity was determined after solubilizing $50 \mu \mathrm{l}$ of the infusate in $100 \mu \mathrm{l}$ solubilizing agent (Protosol; New England Nuclear, Ma., USA).

Glycerol. Plasma glycerol concentrations were determined in un-neutralized perchlorate supernatant fractions by the glycerol dehydrogenase $(E C 1.1,1.6)$ method described by Boobis \& Maughan (1983). The plasma SRA of $\left[2-{ }^{3} \mathrm{H}\right]$ glycerol was determined by a modification of the method of Friedmann et al. (1970). Plasma $(0.5 \mathrm{ml})$ was added to $2.5 \mathrm{ml}$ distilled water, $1.0 \mathrm{ml}$ barium hydroxide $(0.3 \mathrm{~mol} / \mathrm{l})$ and $1.0 \mathrm{ml}$ zinc sulphate $(50 \mathrm{~g} / 1)$ and centrifuged for $15 \mathrm{~min}$ at $2000 \mathrm{~g}$ and $4^{\circ}$. Glucose oxidase (EC 1.1.1.34; $120 \mathrm{U}$ Type VII; Sigma) and $100 \mu \mathrm{l}$ sodium azide $(40 \mathrm{~g} / \mathrm{l})$ were added to $2 \cdot 0 \mathrm{ml}$ of the supernatant fraction and incubated overnight at $37^{\circ}$. The incubated sample was then passed through an anionexchange column $(40 \times 8 \mathrm{~mm}$, Ag-X8 200-400 mesh, acetate form; Bio-Rad Lab., Ca., USA) and the eluate collected into a scintillation vial. Two $1 \mathrm{ml}$ washings of distilled water were added to the column, followed by another $2 \mathrm{ml}$ distilled water. The eluate was dried under a stream of $\mathrm{N}_{2}$ at $50^{\circ}$ to remove tritiated water (TOH) and reconstituted in $1 \mathrm{ml}$ distilled water and $10 \mathrm{ml}$ scintillation cocktail. An additional $1.0 \mathrm{ml}$ supernatant fraction not incubated with glucose oxidase was treated similarly to correct for any radioactivity associated with glucose and not converted to gluconate and retained on the column. The efficiency of conversion of glucose to gluconate in plasma spiked with $\left[\mathrm{U}-{ }^{14} \mathrm{C}\right]$ glucose and subsequent removal of label by column chromatography was 96.5 (SE $0 \cdot 15) \%(n 14)$. The recovery of added $\left[2-{ }^{3} \mathrm{H}\right]$ glycerol was $100 \cdot 6$ (SE $\left.0 \cdot 5\right) \%(n 10)$.

Glucose. Plasma glucose was determined using a commercial glucose oxidase kit (Boehringer Mannheim, West Germany).

Calculations and statistics. Whole-body NER and GER were calculated by dividing the infusion rate (disintegrations/min per $h$ ) of $\left[1-{ }^{14} \mathrm{C}\right] \mathrm{NEFA}$ and $\left[2{ }^{3} \mathrm{H}\right] \mathrm{glycerol}$ by the plasma SRA after the latter was no longer time-dependent. The rise to plateau SRA of both 
Table 1. Plasma metabolite concentrations and whole-body lipid kinetic estimates in ten lactating goats at three stages of lactation

\begin{tabular}{|c|c|c|c|c|}
\hline & Mean & Mean & Mean & $\begin{array}{c}\text { Pooled SE } \\
\text { (18 df })\end{array}$ \\
\hline Day of lactation... & 10 & 38 & 76 & \\
\hline Plasma NEFA $(\mu \mathrm{mol} / 1)$ & $328^{a}$ & $196^{b}$ & $186^{b}$ & $17 \cdot 4$ \\
\hline NEFA entry rate $(\mu \mathrm{mol} / \mathrm{h}$ per $\mathrm{kg})$ & $324^{a}$ & $210^{\mathrm{b}}$ & $191^{\circ}$ & $25 \cdot 7$ \\
\hline NEFA clearance $(\mathrm{ml} / \mathrm{min}$ per $\mathrm{kg})$ & $16 \cdot 3$ & $17 \cdot 4$ & $16 \cdot 7$ & $0 \cdot 397$ \\
\hline Plasma glycerol $(\mu \mathrm{mol} / \mathrm{l})$ & $37 \cdot 8$ & $38 \cdot 2$ & $36 \cdot 6$ & $1 \cdot 72$ \\
\hline Glycerol entry rate $(\mu \mathrm{mol} / \mathrm{h}$ per $\mathrm{kg})$ & $144^{\mathrm{a}}$ & $172^{\mathrm{ab}}$ & $206^{b}$ & $11 \cdot 3$ \\
\hline Glycerol clearance $(\mathrm{ml} / \mathrm{min}$ per $\mathrm{kg})$ & $64 \cdot 1^{\mathrm{a}}$ & $77 \cdot 2^{a b}$ & $92 \cdot 3^{b}$ & $3 \cdot 73$ \\
\hline NEFA re-esterification $(\mu \mathrm{mol} / \mathrm{h}$ per $\mathrm{kg})$ & $109^{\mathrm{a}}$ & $344^{\mathrm{b}}$ & $427^{\mathrm{b}}$ & $41 \cdot 3$ \\
\hline NEFA : glycerol entry rates & $2 \cdot 47^{a}$ & $1 \cdot 34^{\text {in }}$ & $0.98^{\mathrm{h}}$ & $0 \cdot 178$ \\
\hline Plasma glucose $(\mathrm{mmol} / \mathrm{l})$ & $3 \cdot 05^{a}$ & $3 \cdot 36^{b}$ & $3 \cdot 30^{\mathrm{ab}}$ & 0.069 \\
\hline
\end{tabular}

NEFA, non-esterified fatty acids.

a.b Mean values in the same row with different superscript letters were significantly different $(P<0.05)$.

metabolites occurred rapidly and in all goats was achieved within $1 \mathrm{~h}$. Plasma clearance of NEFA and glycerol were calculated by dividing their respective infusion rates by total disintegrations/min per ml plasma at plateau SRA. Apparent NEFA re-esterification was calculated as $(3 \times$ GER $)-N E R$. The underlying assumptions in this calculation are that (1) adipose tissue contains negligible glycerol kinase activity and consequently all glycerol liberated during lipolysis is released into the exchangeable pool of free glycerol, and (2) there is no partial hydrolysis of triacylglycerol.

Maintenance requirements were assumed to be $0.312 \mathrm{MJ} \mathrm{ME} / \mathrm{kg}$ live weight ${ }^{0.75}$ per d (Armstrong \& Blaxter, 1965). Milk energy was calculated from the fat, protein and lactose contents of milk using equation 1 from Tyrrell \& Reid (1965). The partial efficiency of conversion of ME to milk energy $\left(k_{1}\right)$ was assumed to be 0.62 (Agricultural Research Council, 1980). Energy balance was calculated as ME intake less ME for maintenance and milk production.

Statistical and regression analyses were performed using Minitab version $5 \cdot 1$ (Ryan et al. 1985) and Statistical Analysis System (1982; SAS). Stage of lactation effects were assessed using analysis of variance with goat and stage of lactation being the main effects and the interaction being the error term.

\section{RESULTS}

Milk production, dry matter intake, energy balance and estimates of body composition for these animals have been reported elsewhere (Dunshea et al. 1990). These goats had rather modest milk yields, peaking at 2.42 (SE $0 \cdot 13) \mathrm{kg} / \mathrm{d}$ between 5 and 7 weeks post-partum. Dry matter intake, and consequently energy balance, increased as lactation advanced. Calculated energy balance was $-4.92,-0.16$ and $1.70 \mathrm{MJ} \mathrm{ME} / \mathrm{d}$ at days 10,38 and 76 post-partum respectively.

NEFA metabolism. Plasma NEFA concentrations and NER decreased as lactation advanced, being significantly higher at day 10 than at either days 38 and 76 of lactation (Table 1; $P<0.001$ ). Plasma concentrations of NEFA were highly and positively correlated with whole-body NER (Fig. 1 and Table $2 ; r 0.959, P<0.001$ ) and inversely related to calculated energy balance (Fig. 2, $r 0.832, P<0.001$ ). NER was also negatively correlated with energy balance $(X, \mathrm{MJ} \mathrm{ME} / \mathrm{d})$ :

$$
\text { NER }(\mu \mathrm{mol} / \mathrm{kg} \text { per } \mathrm{h})=189 e^{-0 \cdot 128 X}(r-0.812, P<0.001) \text {. }
$$




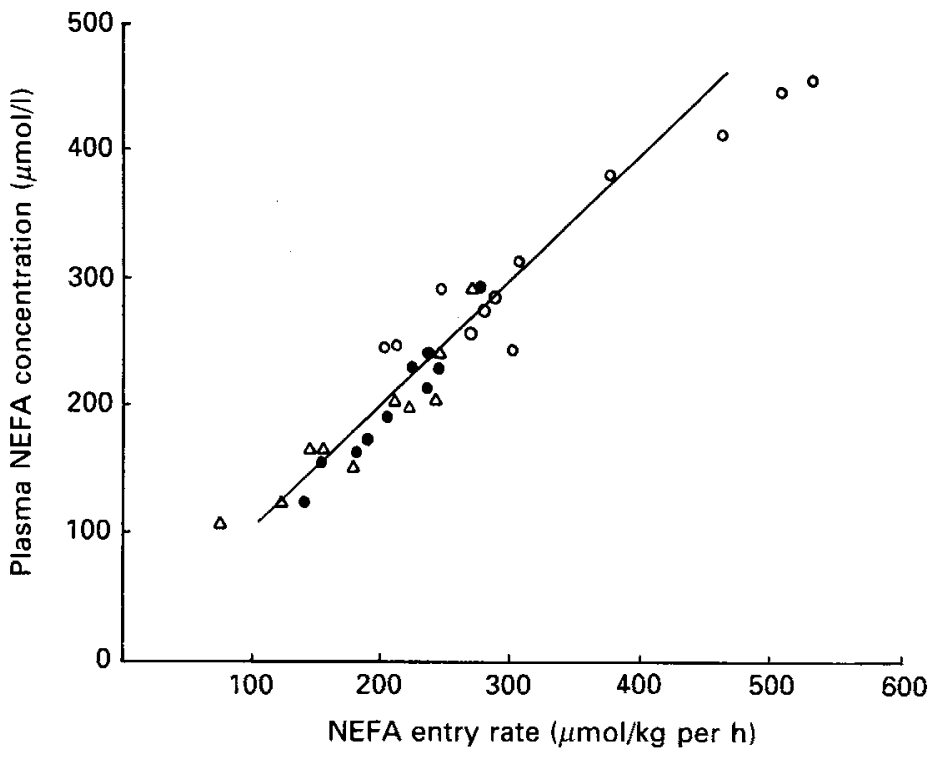

Fig. 1. Relationship between plasma non-esterified fatty acid (NEFA) concentrations and NEFA entry rate in lactating goats at $10(O), 38(O)$ and $76(\triangle)$ d post-partum. $Y=-5.99+1.01 X ; r 0.959$.

Table 2. Linear correlation coefficients for relations between plasma metabolite concentrations, metabolite kinetics and production variables in lactating goats at days 10 (n 12), 38 (n 10) and 76 (n 10) post-partum*

\begin{tabular}{|c|c|c|c|c|c|}
\hline & $\begin{array}{c}\text { Plasma } \\
\text { NEFA } \\
(\mu \mathrm{mol} / 1)\end{array}$ & $\begin{array}{l}\text { NEFA } \\
\text { entry rate } \\
(\mu \mathrm{mol} / \mathrm{h} \\
\text { per } \mathrm{kg})\end{array}$ & $\begin{array}{l}\text { Plasma } \\
\text { glycerol } \\
(\mu \mathrm{mol} / 1)\end{array}$ & $\begin{array}{c}\text { Glycerol } \\
\text { entry rate } \\
(\mu \mathrm{mol} / \mathrm{h} \\
\text { per } \mathrm{kg})\end{array}$ & $\begin{array}{c}\text { Plasma } \\
\text { glucose } \\
(\mathrm{mmol} / \mathrm{l})\end{array}$ \\
\hline NEFA entry rate $(\mu \mathrm{mol} / \mathrm{h}$ per $\mathrm{kg})$ & 0.959 & & & & \\
\hline Plasma glycerol $(\mu \mathrm{mol} / \mathrm{l})$ & $0 \cdot 221$ & $0 \cdot 298$ & & & \\
\hline Glycerol entry rate $(\mu \mathrm{mol} / \mathrm{h}$ per $\mathrm{kg})$ & $-0 \cdot 212$ & $-0 \cdot 155$ & 0.551 & & \\
\hline Plasma glucose $(\mathrm{mmol} / \mathrm{l})$ & -0.458 & $-0 \cdot 354$ & 0.003 & $0 \cdot 158$ & \\
\hline \multicolumn{6}{|l|}{ Milk } \\
\hline Yield $(\mathrm{kg} / \mathrm{d})$ & $0 \cdot 356$ & 0.487 & $0 \cdot 297$ & $0 \cdot 230$ & $0 \cdot 179$ \\
\hline Fat $(g / d)$ & 0.525 & 0.611 & $0 \cdot 230$ & 0.032 & 0.002 \\
\hline Lactose $(\mathrm{g} / \mathrm{d})$ & $0 \cdot 387$ & $0 \cdot 500$ & $0 \cdot 251$ & $0 \cdot 167$ & 0.114 \\
\hline Energy balance (MJ ME/d) & -0.810 & -0.785 & -0.071 & 0.437 & 0.434 \\
\hline $\mathrm{ME}$ intake $(\mathrm{MJ} \mathrm{ME} / \mathrm{d})$ & $-0 \cdot 370$ & $-0 \cdot 237$ & $0 \cdot 207$ & 0.575 & 0.485 \\
\hline
\end{tabular}

NEFA, non-esterified fatty acids; ME, metabolizable energy.

* For $r>0.349$ or 0.449 then $P<0.05$ or 0.01 respectively ( $30 \mathrm{df}$ ).

There were no effects of either stage of lactation or energy balance on NEFA clearance (Table 1). Plasma NEFA concentrations and NER were positively correlated with milk fat yield (Table $2 ; P<0 \cdot 01$ ).

The molar proportions of the major plasma NEFA at each stage of lactation are given in Table 3. Palmitic, stearic and oleic acids constituted at least 0.85 of total NEFA. Proportions of palmitoleic and linoleic acids were higher and oleic acid lower at days 38 and 76 of lactation than at day $10(P<0.05)$. Proportions of stearic acid were significantly 


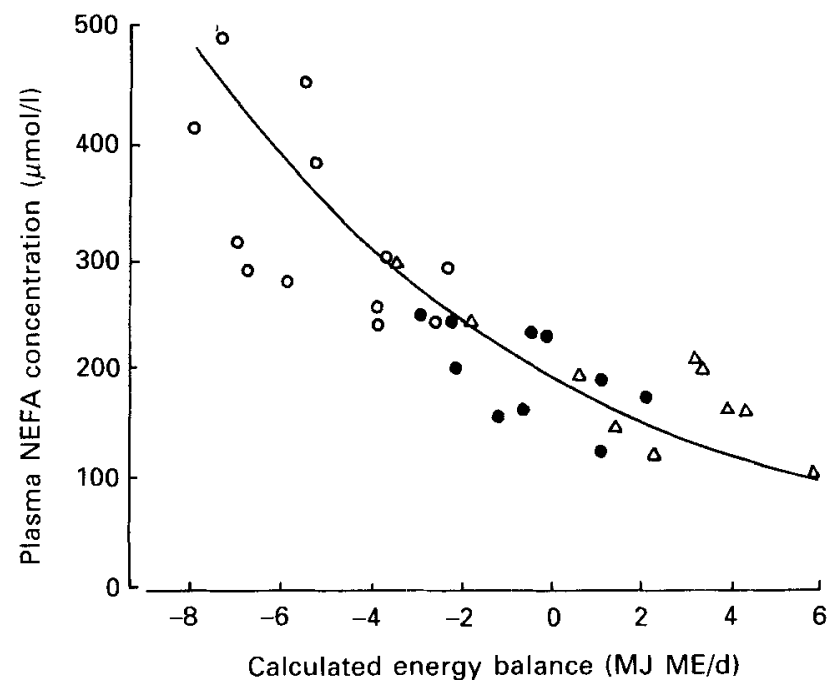

Fig. 2. Relationship between plasma non-esterified fatty acid (NEFA) concentrations and calculated energy balance in lactating goats at $10(\mathrm{O}), 38(O)$ and $76(\triangle) \mathrm{d}$ post-partum. $Y=191 e^{-0 \cdot 118 x} ; r-0.832$. ME, metabolizable energy.

Table 3. The molar proportions of individual non-esterified fatty acids (NEFA) ( $\mathrm{mmol} / \mathrm{mol}$ ) in plasma obtained from ten lactating goats at three stages of lactation

\begin{tabular}{lcccc}
\hline \hline & Mean & Mean & Mean & Pooled sE \\
Day of lactation ... & 10 & 38 & 76 & \\
NEFA & & & & \\
\hline $14: 0$ & 25 & 35 & 29 & $3 \cdot 1$ \\
$16: 0$ & 205 & 194 & 199 & $2 \cdot 1$ \\
$16: 1$ & $17^{\mathrm{a}}$ & $21^{\mathrm{b}}$ & $23^{\mathrm{b}}$ & $1 \cdot 0$ \\
$18: 0$ & $392^{\mathrm{a}}$ & $419^{\mathrm{b}}$ & $398^{\mathrm{ab}}$ & $5 \cdot 7$ \\
$18: 1$ & $297^{\mathrm{a}}$ & $257^{\mathrm{b}}$ & $256^{\mathrm{b}}$ & $6 \cdot 2$ \\
$18: 2$ & $51^{\mathrm{a}}$ & $62^{\mathrm{b}}$ & $82^{\mathrm{c}}$ & $3 \cdot 1$ \\
Other & 13 & 13 & 13 & $1 \cdot 0$ \\
\hline
\end{tabular}

$a, b, c$ Mean values in the same row with different superscript letters were significantly different $(P<0 \cdot 05)$.

increased at day 38 but not at day 76 of lactation. The molar concentration ratio of stearic acid: oleic acid $(\mathrm{S}: \mathrm{O})$ was lower at $10 \mathrm{~d}$ than at either 38 or $76 \mathrm{~d}$ of lactation $(P<0.05)$ and was positively correlated with energy balance $(r 0.592, P<0.01)$.

Glycerol metabolism. Plasma glycerol concentrations and GER were significantly correlated but the relationship was not as strong as for NEFA (Fig. $3 ; r 0.551, P<0.05$ ). However, there appeared to be a stage-of-lactation effect on the correlation between plasma glycerol concentrations and GER, because it was strengthened by removal of the values for day 10 of lactation (Fig. $3 ; r 0.731, P<0.001$ ). This may be partly because glycerol clearance was significantly lower at day 10 than at day 76 of lactation (Table $1 ; P<0.001$ ). GER was positively correlated with energy balance and ME intake (Table 2; $P<0.05$ and $0 \cdot 01$ respectively).

NEFA re-esterification. Apparent NEFA re-esterification was positively correlated with energy balance (Fig. $4 ; r 0.711$ ), increasing as lactation advanced (Table $1 ; P<0.01$ ). 


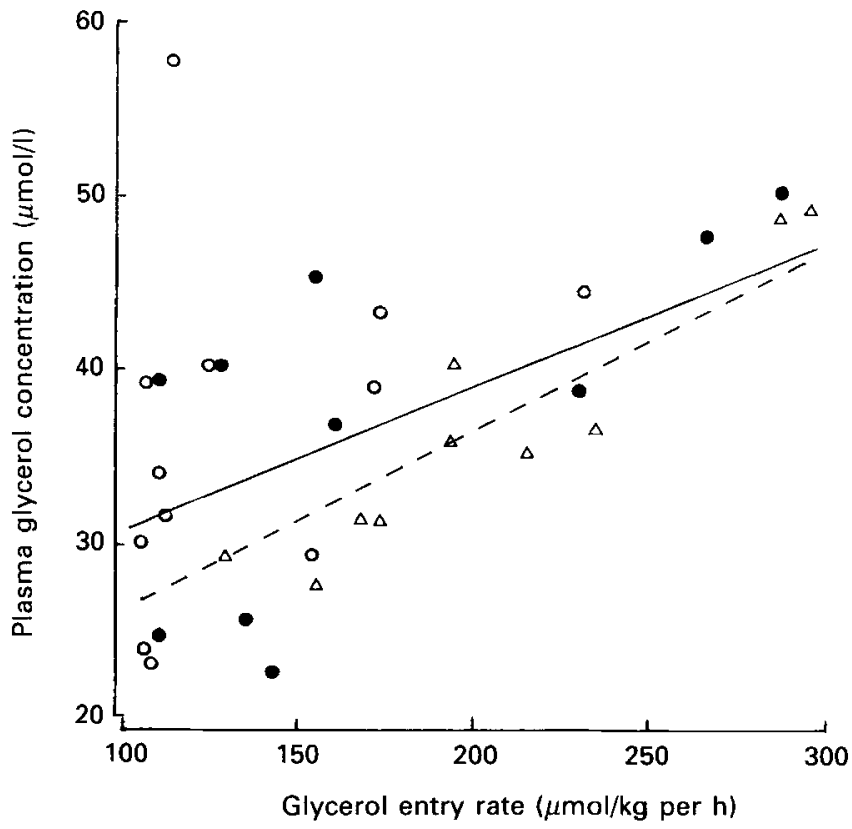

Fig. 3. Relationship between plasma glycerol concentrations and glycerol entry rate in lactating goats at $10(O)$, $38(\triangle)$ and $76(\triangle)$ d post-partum. ( $\longrightarrow, Y=22 \cdot 8+0.0826 X ; r 0.551$ (all values); $(-----), Y=17 \cdot 6+0 \cdot 103 X$; $r 0.731$ (days 38 and 76 post-partum only).

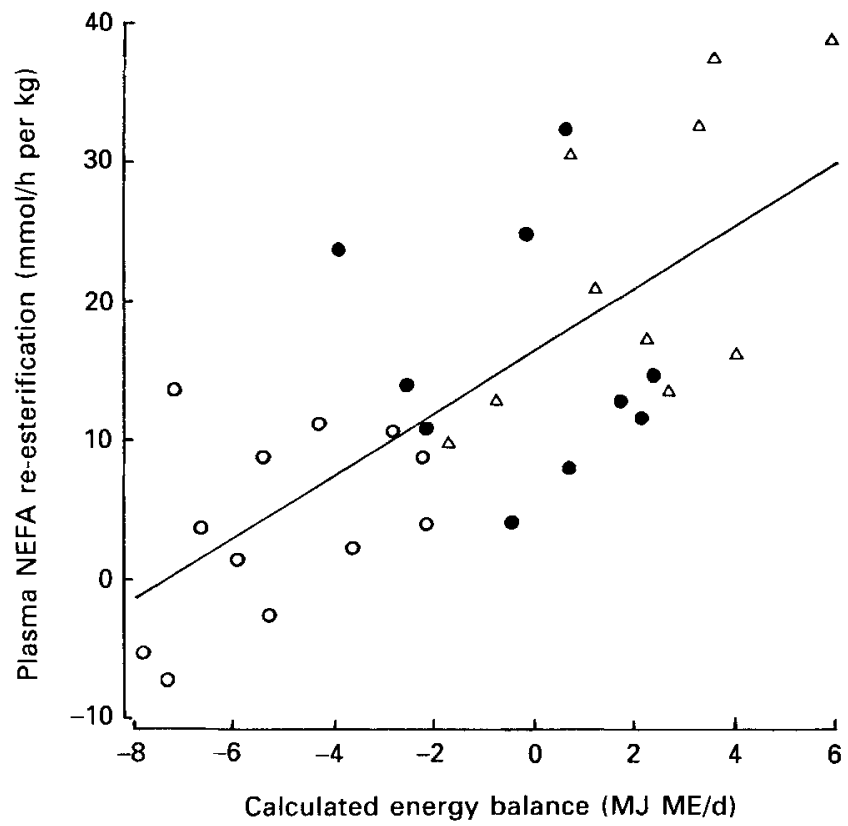

Fig. 4. Relationship between plasma non-esterified fatty acid (NEFA) re-esterification and calculated energy balance in lactating goats at $10(\mathrm{O}), 38(O)$ and $76(\triangle) \mathrm{d}$ post-partum. $Y=16 \cdot 6+2 \cdot 26 X ; r 0 \cdot 71 \mathrm{l}$. ME, metabolizable energy. 




Fig. 5. Relationship between non-esterified fatty acid: glycerol entry rates (NER:GER) and calculated energy balance in lactating goats at $10(\mathrm{O}), 38(O)$ and $76(\triangle) \mathrm{d}$ post-partum. $Y=1 \cdot 10 e^{-0 \cdot 181 x}, r-0.833$. ME, metabolizable energy.

Another index of apparent NEFA re-esterification, the ratio NER:GER, was negatively related to energy balance (Fig. $5 ; r-0.833$ ) and decreased from a mean value of 2.47 at day 10 to 1.34 and 0.98 at days 38 and 76 of lactation respectively (Table $1 ; P<0.001$ ).

Glucose. Plasma glucose concentration increased between days 10 and 38 of lactation (Table $1 ; P<0.05$ ) and was positively correlated with both $\mathrm{ME}$ intake and energy balance but not with either milk or milk lactose yield (Table 2). Plasma glucose concentrations were inversely related to both plasma NEFA concentrations and NER (Table 2).

Changes in body composition. Changes in body composition of these goats over the two periods of lactation (days 10-38 and days 38-76) are reported in a companion paper (Dunshea et al. 1990). Consistent with calculated energy balance values, estimated body fat mobilization between days 10 and 38 post-partum was 59 (SE 18) g/d. There was no significant change in estimated body fat between days 38 and 76 of lactation. Relationships between indices of lipid status at days 10 and 38 of lactation and subsequent fat mobilization are given in Table 4. Plasma glucose concentrations were negatively correlated with subsequent fat loss. Indices of NEFA re-esterification were more highly correlated with estimated fat mobilization than were either plasma NEFA concentrations or NER.

\section{DISCUSSION}

The high correlations between plasma NEFA concentrations and NER in the present study in multiparous goats confirms our findings in primiparous lactating goats (Dunshea et al. 1989). However, while the slope of the regression line describing the relationship was similar in the two groups of animals, the intercepts were significantly different. NEFA distribution space approximates plasma volume (Jackson et al. 1968), which in turn is more highly correlated with the fat-free empty body (FFEB) mass than with live weight (Doornenbal et al. 1962; Panaretto \& Little, 1965). As the primiparous goats were leaner than the 
Table 4. Relationships between indices of lipid status at either days 10 or 38 and estimated fat mobilization $(\triangle F A T, \mathrm{~g} / d)$ over the subsequent stage of lactation

(Model is: component $=a+b \Delta \operatorname{FAT}(n 20,18 \mathrm{df})$ )

\begin{tabular}{lcccc}
\hline \hline Component & $a$ & $b$ & SE & $r$ \\
\hline Plasma NEFA $(\mu \mathrm{mol} / \mathrm{l})$ & & 0.646 & 0.318 & $0.432 \dagger$ \\
NEFA entry rate $(\mathrm{g} / \mathrm{d})$ & 250 & 0.216 & 0.114 & $0.407 \dagger$ \\
Plasma glycerol $(\mu \mathrm{mol} / \mathrm{l})$ & $91 \cdot 1$ & -0.0229 & 0.0362 & -0.148 \\
Glycerol entry rate $(\mathrm{g} / \mathrm{d})$ & $37 \cdot 3$ & -0.0407 & 0.0186 & $-0.459^{*}$ \\
Plasma glucose $(\mathrm{mmol} / \mathrm{l})$ & $18 \cdot 2$ & -0.00260 & 0.000911 & $-0.560^{* *}$ \\
NEFA $:$ glycerol entry rates & 3.24 & 0.00807 & 0.00291 & $0.548^{*}$ \\
NEFA re-esterification $(\mathrm{g} / \mathrm{d})$ & 75.1 & -0.587 & 0.190 & $-0.589^{* *}$ \\
\hline
\end{tabular}

NEFA, non-esterified fatty acids.

${ }^{*} P<0.05,{ }^{* *} P<0 \cdot 01,+P<0 \cdot 10$.

multiparous goats, and because we had estimates of FFEB from TOH kinetics in both groups of animals, present values were also analysed on this basis. Neither the intercepts nor the slopes were significantly different between the two groups, so the values were pooled. The resultant equation was NER $(\mu \mathrm{mol} / \mathrm{h}$ per $\mathrm{kg}$ FFEB) $=-6 \cdot 12+2 \cdot 48$ [NEFA] $(\mu \mathrm{mol} / \mathrm{l})(r 0.904, P<0.001, n 44)$. These findings constitute a large proportion of the in vivo information on NEFA kinetics in fed, lactating goats and clearly demonstrate that plasma concentrations of NEFA and NER are highly correlated over a range of energy balances and stages of lactation as is the case in dairy cows (Bauman et al. 1988).

Plasma clearance of a metabolite is the volume of plasma that is completely cleared of the metabolite per unit time. As NEFA are essentially confined to a small space in the body, putatively the plasma pool (Jackson et al. 1968), and fractional uptake by many tissues is relatively constant (Bell, 1981), it is not surprising that NEFA clearance did not differ between stages of lactation, being approximately $17 \mathrm{ml} / \mathrm{kg}$ per min. On the other hand, glycerol clearance increased from 63 to $92 \mathrm{ml} / \mathrm{kg}$ per min between days 10 and 76 of lactation, which may explain the relatively poor correlations between plasma glycerol concentrations and GER in the present study.

Unlike that for NEFA, the estimated volume of distribution for glycerol is large, being approximately $30 \%$ of live weight, and does not correspond to any directly measurable physiological space (Wade, 1981). It is probable that glycerol does not exist in a single homogeneous pool but rather in a matrix of concentration gradients, with clearance from and entry into plasma being very much dependent on these gradients. Although reasons for the increase in glycerol clearance as lactation advances are unknown, they could include increased efficiency of uptake and utilization by tissues, changes in the partitioning of blood flow between glycerol-producing and glycerol-utilizing tissues or be related to heterogeneity of the free glycerol pool. It should be borne in mind that very little is known about glycerol metabolism in ruminants, particularly lactating animals. Bergman (1968) showed a close correlation between plasma glycerol concentration and GER in non-pregnant and ketotic pregnant sheep. However, the upper values for GER were achieved by either exogenous infusion of epinephrine or glycerol. Consequently, the range in plasma concentrations of glycerol was almost tenfold, whereas in the present study it was less than threefold. Therefore, large, acute increases in GER caused by infusion of epinephrine or glycerol do not alter glycerol clearance in sheep. However, with low GER, such as observed in the present study, a greater proportion of the variation in glycerol concentration may be attributed to variation in clearance (Wade, 1981). 
The inverse correlations between energy balance and both plasma NEFA concentrations and NER is evidence of increased fat mobilization during periods of energy deficit. Similar relations between NER and energy balance or stage of lactation have been observed in lactating dairy cows (Konig et al. 1979; Bauman et al. 1988; Pullen et al. 1989) and between plasma NEFA concentrations and energy balance in lactating goats (Chilliard et al. 1987). While these findings may suggest that whole-body lipolysis is highest in early lactation when the goats were in most severe negative energy balance, the glycerol kinetic findings do not support this. GER increased with advancing lactation and was positively, rather than negatively, correlated with both energy balance and ME intake. Similarly, Smith \& Walsh (1984) found that glycerol release in vitro from isolated adipocytes prepared from sheep omental adipose tissue increased almost threefold between days 20 and 40 postpartum. In another series of studies in dairy heifers there were either slight increases or no change in glycerol release from incubated subcutaneous adipose tissue over the first 8 months of lactation (McNamara \& Hillers, 1986; McNamara, 1988; 1989).

GER is a measure of whole-body lipolysis, most of which is generally assumed to occur within adipocytes. As the activity of glycerol kinase is extremely low in adipose tissue (Shirley et al. 1973), glycerol liberated during lipolysis diffuses into the body pool of free glycerol. NEFA that enter the circulation are also thought to arise from adipose tissue triacylglycerol lipolysis, although some NEFA can be re-esterified within the adipocyte itself. The present findings highlight the distinction between lipolysis and NER or fat mobilization as well as the importance of intracellular re-esterification. If, for simplicity, it is assumed that all glycerol and NEFA entering the free pools arise from adipose tissue lipolysis, then even at zero energy balance re-esterification accounted for over $50 \%$ of the fatty acids arising from lipolysis in lactating goats. This proportion was much reduced when the goats were in large energy deficits. Using similar in vivo techniques, Wilson (1983) estimated that NEFA re-esterification accounted for 67 and $53 \%$ of NEFA released during lipolysis in well-fed and under-fed late-pregnant ewes respectively. GER did not differ in these two groups of sheep, which implies that undernourished pregnant sheep can increase fat mobilization via decreasing intracellular fatty acid re-esterification without increasing lipolysis. Similarly, the present findings suggest that the decreased fat mobilization which progressively occurs between days 10 and 76 of lactation in goats is not necessarily caused by decreased lipolysis. Also, Hansson et al. (1987) found the absolute rate of in vivo adipose tissue re-esterification to be low in lactating rats, increasing ninefold after weaning. However, the proportions of adipose tissue triacylglycerol fatty acids resulting from reesterification were similar in both physiological states (approximately $90 \%$ ).

Decreased rates of re-esterification during early lactation have also been observed in vitro. Metz \& van den Bergh (1977) showed that in adipose tissue obtained from dairy cows, the ratio of NEFA: glycerol release increased from unity during late pregnancy to approximately two immediately before parturition and ultimately three during the first 4 weeks of lactation. Similarly, McNamara \& Hillers (1986) found that in adipose tissue obtained from dairy heifers over the interval 1 month pre-partum to 1 month post-partum, in vitro NEFA and glycerol release remained constant. Although NEFA increased slightly $(11 \%)$ at 2 and 6 months post-partum, rates of glycerol release at the same times were 43 and $210 \%$ greater respectively, than during the parturient period. Consequently, NEFA reesterification must also have increased. In addition, esterification of palmitate and de novo lipogenesis from acetate in adipose tissue in vitro increased much more markedly over this period, thereby ensuring net lipid deposition (McNamara \& Hillers, 1986).

Explanations for the lack of a decrease in lipolysis and the increase in subsequent recycling of NEFA as the goats moved into positive energy balance can only be speculated upon. Newsholme (1987) points out that re-esterification (or recycling) provides a 
mechanism for fine tuning the lipid synthesis-breakdown cycle to meet acute shifts in energy demands. The existence of this cycle may help explain why NER does not continue to decline markedly as energy balance exceeds zero. Another role for high rates of reesterification during chronic positive energy balance could be to ensure that lipogenesis is not limited by cytosolic ATP accumulation. De novo fatty acid synthesis from glucose results in a net production of ATP and it has been proposed that re-esterification is a means by which ATP homeostasis is maintained (Flatt, 1970). However, acetate is the major precursor for de novo fatty acid synthesis in the ruminant and the net generation of ATP depends on the pathway by which reducing equivalents are generated. If NADPH is generated entirely from involvement of glucose in the pentose-phosphate cycle there will be a net utilization of ATP. Conversely, if NADPH is produced from acetate via the isocitrate cycle then a net generation of ATP occurs (Bauman \& Davis, 1975). In this case, continual lipolysis and adequate re-esterification could ensure ongoing de novo fatty acid synthesis and net triacylglycerol deposition.

The lactating ruminant mammary gland simultaneously takes up and releases plasma NEFA, the relative magnitude of the two fluxes depending on the animal's energetic status. In the lactating dairy cow, Kronfeld (1965) found a positive correlation between arterial plasma NEFA concentrations and mammary arterio-venous (a-v) plasma NEFA differences over the range 120-750 $\mu \mathrm{mol} / 1$, with zero a-v differences occurring at about 250-300 $\mu \mathrm{mol} / 1$. At lower plasma NEFA concentrations there was a net release of NEFA across the mammary gland with substantial dilution of plasma NEFA SRA in studies where labelled NEFA were infused (Annison et al. 1967; West et al. 1972). Calculations based on published values suggest that release of unlabelled palmitic or oleic acids across the mammary gland accounted for between 0 and $25 \%$ of whole-body entry rate of these NEFA in lactating sheep (King, 1983), goats (Annison et al. 1967; West et al. 1972) and cows (Annison et al. 1974), the lower values being found in animals which were fed on highroughage diets or were in substantial energy deficit. Also, mammary a-v and mixed NEFA SRA differences in lactating goats at approximately zero energy balance suggested that release of NEFA by the mammary gland contributed about $30 \%$ of NER (Dunshea, 1987). The considerable contribution of mammary triacylglycerol hydrolysis to NER may be another partial explanation for the plateau in both plasma NEFA concentrations and NER as energy balance approaches and exceeds zero.

In a previous study we found both plasma NEFA concentrations and NER to be significantly correlated with estimated body fat loss over the subsequent stage of lactation in primiparous goats fed ad lib. (Dunshea et al. 1989). Also, changes in body fat were highly correlated with and of a similar magnitude to changes in NER in chronically undernourished non-lactating, non-pregnant goats (Dunshea et al. 1988 b). Chilliard et al. (1984) observed a high correlation ( $r$ 0.95) between average prefeeding plasma NEFA levels and changes in estimated body fat in lactating dairy cows. They noted that the relationship was more useful in cows fed on a restricted ration. Body composition of the goats used in the present study was estimated at the same time as the metabolic studies were done (Dunshea et al. 1990). Correlations between NEFA or glycerol kinetic measurements and estimated body fat mobilization were significant but relatively low, perhaps because kinetic measurements were obtained only three times during early lactation while the goats were fed ad lib. This would have allowed the goats to adjust feed intake to meet their energy requirements in the interim between metabolic measurements. The higher correlations between indices of NEFA re-esterification and subsequent fat mobilization is further evidence that as an animal increases energy balance the rates of de novo lipogenesis and NEFA re-esterification may be more important than lipolysis as determinants of fatty acid release from adipose tissue. 
The present study showed that during early lactation, body fat can be mobilized at substantial rates, even in goats fed $a d$ lib. and with relatively modest milk yields. Subsequent changes in the balance between adipose tissue lipid accretion and depletion appeared to be achieved largely through altered rates of fatty acid re-esterification and lipogenesis. Future studies should seek to determine the relative importance of these variables as key points of regulation of lipid balance during changes in physiological or nutritional states, or both.

The authors wish to thank Mr K. D. Chandler, Miss R. Fitzpatrick and Miss R. Vavala for technical assistance and care of the animals. F.R.D. was supported by a grant from the Australian Dairy Research Committee.

\section{REFEREN CES}

Agricultural Research Council (1980). The Nutrient Requirements of Ruminant Livestock. Slough : Commonwealth Agricultural Bureaux.

Anderson, L. E. \& MacClure, W. O. (1973). An improved scintillation cocktail of high-solubilizing power. Analytical Biochemistry 51, 173-179.

Annison, E. F., Bickerstaffe, R. \& Linzell, J. L. (1974). Glucose and fatty acid metabolism in cows producing milk of low fat content. Journal of Agricultural Science, Cambridge 82, 87-95.

Annison, E. F., Brown, R. E., Leng, R. A., Lindsay, D. B. \& West, C. E. (1967). Rates of entry and oxidation of acetate, glucose, $\mathrm{D}(-)$ - $\beta$-hydroxybutyrate, palmitate, oleate and stearate, and rates of production and oxidation of propionate and butyrate in fed and starved sheep. Biochemical Journal 104, 135-147.

Armstrong, D. G. \& Blaxter, K. L. (1965). Effects of acetic and propionic acids on energy retention and milk secretion in goats. In Energy Metabolism, pp. 59-72 [K. L. Blaxter, editor]. London: Academic Press.

Bauman, D. E. \& Davis, C. L. (1975). Regulation of lipid metabolism. In Digestion and Metabolism in the Ruminant, pp. 496-509 [I. W. McDonald and A. C. I. Warner, editors]. Armidale: University of New England Publishing Unit

Bauman, D. E., Peel, C. J., Steinhour, W. D., Reynolds, P. J., Tyrrell, H. F., Brown, A. C. G. \& Haaland, G. L. (1988). Effect of bovine somatotropin on metabolism of lactating dairy cows: influence on rates of irreversible loss and oxidation of glucose and nonesterified fatty acids. Journal of Nutrition 118, 1031-1047.

Bell, A. W. (1981). Lipid metabolism in liver and selected tissues and in the whole body of ruminant animals. In Lipid Metabolism in Ruminant Animals, pp. 363410 [W. W. Christie, editor]. Oxford: Pergamon Press.

Bergman, E. N. (1968). Glycerol turnover in the nonpregnant and ketotic pregnant sheep. American Journal of Physiology 215, 865-873.

Boobis, L. H. \& Maughan, R. J. (1983). A simple one-step enzymatic fluorometric method for the determination of glycerol in $20 \mu$ of plasma. Clinica Chimica Acta 132, 173-179.

Chilliard, Y., Robelin, J. \& Remond, B. (1984). In vivo estimation of body lipid mobilization and reconstitution in dairy cattle. Canadian Journal of Animal Science 64, Suppl., 236-237.

Chilliard, Y., Sauvant, D., Morand-Fehr, P. \& Delouis, C. (1987). Relations entre le bilan énergétique et l'activité métabolique du tissu de la chevre au cours de la première moitié de la lactation. Reproduction, Nutrition, Développement 27, 307-308.

Doornenbal, H., Asdell, S. A. \& Wellington, G. H. (1962). Chromium-51 determined red cell volume as an index of 'lean body mass' in pigs. Journal of Animal Science 21, 461-463.

Dunshea, F. R. (1987). Use of labile tissue reserves during chronic undernutrition or early lactation in dairy goats. $\mathrm{PhD}$ Thesis, La Trobe University, Bundoora, Australia.

Dunshea, F. R. \& Bell, A. W. (1987). Non-esterified fatty acid (NEFA) re-esterification and fat mobilization in goats during early lactation. Journal of Dairy Science 70, Suppl. 1, 107 Abstr.

Dunshea, F. R. \& Bell, A. W. (1989). Non-esterified fatty acid recycling (re-esterification) and lipid mobilization in goats during early lactation. In Energy Metabolism of Farm Animals, pp. 119-122 [Y. van der Honing and W. H. Close, editors]. Wageningen: Pudoc,

Dunshea, F. R., Bell, A. W., Chandier, K. D. \& Trigg, T. E. (1988a). A two pool model of tritiated water kinetics to predict body composition in unfasted lactating goats. Animal Production 47, 435 445 .

Dunshea, F. R., Bell, A. W. \& Trigg, T. E. (1988b). Relations between plasma non-esterified fatty acid metabolism and body tissue mobilization during chronic undernutrition in goats. British Journal of Nutrition 60, 633-644.

Dunshea, F. R., Bell, A. W. \& Trigg, T. E. (1989). Relations between plasma non-esterified fatty acid metabolism and body fat mobilization in primiparous lactating goats. British Journal of Nutrition 62, 51-61.

Dunshea, F. R., Bell, A. W. \& Trigg, T. E. (1990). Body composition changes in goats during early lactation estimated using a two-pool model of tritiated water kinetics. British Journal of Nutrition 64, 121-131. 
Flatt, J. P. (1970). Conversion of carbohydrate to fat in adipose tissue: an energy yielding and, therefore, selflimiting process. Journal of Lipid Research 11, 131-143.

Friedmann, B., Goodman, E. H. Jr \& Weinhouse, S. (1970). Dietary and hormonal effects on gluconeogenesis and glycogenesis from pyruvate- $3-{ }^{14} \mathrm{C}$, fructose-U $-{ }^{14} \mathrm{C}$ and glycerol-2- ${ }^{14} \mathrm{C}$ in the rat. Endocrinology $86,1264-1271$.

Hansson, P., Newsholme, E. A. \& Williamson, D. H. (1987). Effects of lactation and removal of pups on the rate of triglyceride/fatty acid substrate cycling in white adipose tissue of the rat. Biochemical Journal 243, 267-271.

Hecker, J. F. (1974). Experimental Surgery on Small Ruminants. London: Butterworths.

Jackson, H. D., Black, A. L. \& Moller, F. (1968). Turnover of plasma palmitate in fed and fasted lactating cows. Journal of Dairy Science 51, 1625-1632.

King, K. R. (1983). Lipid metabolism in the lactating ewe. M. Agr. Sci. Thesis, University of Sydney, Sydney, Australia.

Konig, B. A., Parker, D. S. \& Oldham, J. D. (1979). Acetate and palmitate kinetics in lactating dairy cows. Annales de Recherches Vétérinaire 10, 368-370.

Kronfeld, D. S. (1965). Plasma non-esterified fatty acid concentrations in the dairy cow : responses to nutritional and hormonal stimuli, and significance in ketosis. Veterinary Record 77, 30-35.

Lindsay, D. B. \& Leat, W. M. F. (1977). Oxidation and metabolism of linoleic acid in fed and fasted sheep. Journal of Agricultural Science, Cambridge 89, 215-221.

Linzell, J. L. (1966). Infusion and blood sampling techniques for use in minimally restrained goats. Journal of Physiology 186, 79P-81P.

McNamara, J.P. (1988). Regulation of bovine adipose tissue metabolism during lactation. 4. Doseresponsiveness to epinephrine as altered by stage of lactation. Journal of Dairy Science 71, 643-649.

MeNamara, J. P. (1989). Regulation of bovine adipose tissue metabolism during lactation. 5. Relationships of lipid synthesis and lipolysis with energy intake and utilization. Journal of Dairy Science 72, 407-418.

McNamara, J. P. \& Hillers, J. K. (1986). Adaptations in lipid metabolism of bovine adipose tissue in lactogenesis and lactation. Journal of Lipid Research 27, 150-157.

Metz, S. H. M. \& van den Bergh, S. G. (1977). Regulation of fat mobilization in adipose tissue of dairy cows in the period around parturition. Netherlands Journal of Agricultural Science 25, 248-253.

Ministry of Agriculture, Fisheries and Food (1975). Energy Allowances and Feeding Systems for Ruminants. Technical Bulletin no. 33. London: H.M. Stationery Office.

Newsholme, E. A. (1987). Substrate cycles and energy metabolism: their biochemical, biological, physiological and pathological importance. In Energy Metabolism of Farm Animals, pp. 314-317 [P. W. Moe, H. F. Tyrrell and P. J. Reynolds, editors]. New Jersey: Rowman and Littlefield.

Panaretto, B. A. \& Little, D. A. (1965). Body composition in vivo. VII. The relation between red cell volume and total body water in ewes. Australian Journal of Agricultural Research 16, 661-665.

Pethick, D. W., Lindsay, D. B., Barker, P. J. \& Northrop, A. J. (1983). The metabolism of circulating nonesterified fatty acids by the whole animal, hind-limb muscle and uterus of pregnant ewes. British Journal of Nutrition 49, 129-143.

Pullen, D. L., Palmquist, D. L. \& Emery, R. S. (1989). Effect of days of lactation and methionine hydroxy analog on incorporation of plasma fatty acids into plasma triglycerides. Journal of Dairy Science 72, 49-58.

Ryan, T. A. Jr, Joiner, B. L. \& Ryan, B. F. (1985). Minitab: Version 5.I Massachusetts: Duxbury Press.

Statistical Analysis System (1982). SAS User's Guide: Statistics, Cary, NC: SAS Institute, Inc.

Shirley, J. E., Emery, R. S., Convey, E. M. \& Oxender, W. D. (1973). Enzymatic changes in bovine adipose and mammary tissue, serum and mammary tissue hormonal changes with initiation of lactation. Journal of Dairy Science 56, 569-574.

Smith, R. W. \& Walsh, A. (1984). Effect of lactation on the metabolism of sheep adipose tissue. Research in Veterinary Science 37, 320-323.

Tyrrell, H. F. \& Reid, J. T. (1965). Prediction of the net energy value of cow's milk. Journal of Dairy Science 48 , $1215-1223$.

Wade, A. J. (1981). The distribution and metabolism of glycerol in rabbits. Biochemical Journal 196, $547-556$.

West, C. E., Bickerstaffe, R., Annison, E. F. \& Linzell, J. L. (1972). Studies on the uptake of blood triglycerides by the mammary gland of the lactating goat. The uptake and incorporation into milk fat of labelled glycerol, fatty acids and triglycerides. Biochemical Journal 126, 477-490.

Wilson, S. (1983). Apparent re-esterification of fatty acids during lipolysis in pregnant ewes. Proceedings of the Nutrition Society 42, 130A Abstr. 